\title{
The Geography of Housing Market Liquidity During the Great Recession
}

\author{
Mathew Famiglietti, Carlos Garriga, and Aaron Hedlund
}

\begin{abstract}
Using detailed micro data at the ZIP code level, this article explores the regional variation in housing market performance to account for the severity of the Great Recession. The granularity of the data, relative to a more traditional analysis at the county level, is useful for evaluating the performance of the housing market because credit and local macroeconomic variables are tied to housing valuations. The deterioration of the ability to transact (buy and sell) housing units, often referred to as housing liquidity, is an important link that connects housing outcomes with real and credit variables. The data indicate that the timing, severity, and duration of the recession varied across regions and was closely connected with the behavior of the housing market. The deterioration in housing liquidity was uniform across all house price tiers (i.e., bottom, middle, and upper end). Furthermore, there was correlation across areas between the magnitude of the declines in housing liquidity and the severity of the deterioration in house prices and macroeconomic conditions. (JEL D31, D83, E21, E22, G11, G12, G21)
\end{abstract}

Federal Reserve Bank of St. Louis Review, First Quarter 2020, 102(1), pp. 51-77.

https://doi.org/10.20955/r.102.51-77

\section{INTRODUCTION}

The historic deterioration of housing markets during the Great Recession was characterized by plummeting home values and skyrocketing foreclosure rates. Although almost no place in the Unites States escaped unscathed, significant heterogeneity emerged across both time and space with regard to the housing market collapse. An important aspect missing in many theoretical and empirical studies of this episode is the role of liquidity in local housing markets as manifested in homes taking longer to sell.

Examining the dynamics of ZIP-code-level data reveals that the severity, timing, and length of the Great Recession varied across regions and is linked to housing liquidity. Throughout this article, our main measure of housing liquidity is time on the market (TOM), the

The authors thank Juan Sanchez for helpful comments. Mathew Famiglietti is a research associate and Carlos Garriga is an economist and vice president at the Federal Reserve Bank of St. Louis. Aaron Hedlund is a visiting scholar at the Federal Reserve Bank of St. Louis, an assistant professor at the University of Missouri-Columbia, and a visiting senior fellow and acting director of academic outreach at the Center for Growth and Opportunity at Utah State University.

(c) 2020, Federal Reserve Bank of St. Louis. The views expressed in this article are those of the author(s) and do not necessarily reflect the views of the Federal Reserve System, the Board of Governors, or the regional Federal Reserve Banks. Articles may be reprinted, reproduced, published, distributed, displayed, and transmitted in their entirety if copyright notice, author name(s), and full citation are included. Abstracts, synopses, and other derivative works may be made only with prior written permission of the Federal Reserve Bank of St. Louis. 


\section{Famiglietti, Garriga, Hedlund}

number of days between listing a property and selling a property. A mismatch between the number of sellers and buyers changes the transactability of houses beyond house prices. Housing liquidity responds to changing macroeconomic conditions, resulting in selling delays. During the Great Recession, the deterioration in housing liquidity along with falling prices generated an imbalance between assets and liabilities, creating a debt overhang. To rebalance their portfolios, households needed to adjust their spending, liquidate leveraged assets (i.e., housing), and in some instances enter foreclosure, which in turn induced lenders to contract credit.

The National Bureau of Economic Research classifies the Great Recession as occurring from December 2007 to June 2009. However, the national housing market experienced a severe downturn nationally from at least 2006 to 2011 . House prices deteriorated and mortgage delinquency increased as early as 2005 in the regions first affected by the crisis. The earlier start date for the housing crisis is not unexpected, because the subprime mortgage crisis was an important catalyst of the financial recession that followed. Besides starting earlier than the accepted recession dates, the housing market did not fully recover to pre-crisis levels until several years after the official end of the recession: Most areas did not see house prices, liquidity, or income recover to pre-recession levels until after 2011.

Within this window of 2005 to 2011, the various regions of the United States experienced different timing of the start, trough, and end of the housing crisis. For example, the state of California witnessed fairly early declines in housing market indicators but recovered more rapidly than many other regions. Meanwhile, states in the Sunbelt, particularly Florida, Arizona, and Nevada (hereafter called the Sunbelt states), also witnessed early large declines in house prices and increases in illiquidity and mortgage delinquency. These Sunbelt states did not recover until well after the official end date of the recession. Documenting the regional variation in housing market responses (and in particular housing liquidity) during the Great Recession is one of the main goals of this article.

The use of granular data is crucial to the study of housing. Housing markets by nature are disaggregated, as there can be significant variation within counties or metropolitan statistical areas (MSAs). The use of granular data is particularly important when looking at regional variation in the United States. Many western states have significantly larger counties by area than eastern states. Aggregating data to the MSA level, or even to the county level, causes any empirical analysis to ignore significant variation within counties. To alleviate these concerns, the analysis in this article uses ZIP-code-level data.

Several different empirical specifications establish a strong link between explanatory housing market variables (house prices and liquidity) and local outcomes for the credit market (mortgage delinquency) and macroeconomy (income). Moreover, categorizing the geography of the housing crisis into three large regions (California, the Sunbelt states, and the other states) generates heterogeneous effects that substantially differ from those at the national level. For example, in California, house prices declined by more than the national average and mortgage delinquency increased far more than the national average. However, liquidity and income declined by less than the national averages. Although the trough was later in the Sunbelt states, income declined by large amounts and homes' TOM and mortgage delinquencies increased. 
The regression models exploit regional time windows to arrive at (non-causal) estimates of changes in house prices and liquidity on these outcomes. In all cases, the effects were highly statistically and economically significant. For example, at the national level, a one-month increase in TOM is associated with approximately a 1 percent decline in real income. To put these estimates into perspective, a 10 percent decline in house prices is associated with approximately a 1.8 percent decline in real income. For the Sunbelt states, the liquidity effects are slightly larger. Housing liquidity also has strong implications for the mortgage delinquency rate. In California, a one-month increase in TOM is associated with a 2.0 percent increase in the mortgage delinquency rate. Given this observed increase in TOM, the estimate for California predicts a 13.5 increase in mortgage delinquency. For the Sunbelt states, the estimate is 17 percent.

We also estimate alternate specifications of the models by dividing the United States into regions by housing supply elasticity rather than by geography. These estimates provide a counterfactual to the regional analysis and support the claim that liquidity was a highly significant factor in areas with a low housing supply elasticity. We also find that in areas with relatively high housing supply elasticity, liquidity was significant but had a smaller effect on outcomes. We detail in Section VI a brief theory of the interaction of housing liquidity and elasticity.

\section{LITERATURE: HOUSING, THE MACROECONOMY, AND THE GREAT RECESSION}

Traditionally, the role of housing in the macroeconomy was limited to exploring its role over the business cycle through various channels such as residential investment (i.e., Davis and Heathcote, 2005; Leamer, 2007; Fisher and Yavas, 2007; Rupert and Wasmer, 2014; and Boldrin et al. 2013), collateral constraints (i.e., Iacoviello, 2005; Iacoviello and Neri, 2010; and Liu, Wang, and Zha, 2013), and nominal mortgage contracts (i.e., Garriga, Kydland, and Sustek, 2017 and 2019). 1 These papers measure the importance of housing to high-frequency movements of the economy but were not designed to address large and broad swings in house prices across markets and their interaction with the macroeconomy.

There is a growing literature that focuses on this issue and has been summarized by Garriga and Hedlund (forthcoming). The evidence constructed by Jordà, Schularick, and Taylor (2015), who study large movements in housing and equity markets in 17 countries over the past 140 years, appears to be conclusive. Periods with easy credit fueled asset price booms, in particular in housing markets, which increase the risk of a financial crisis. Upon collapse, these episodes tend to be followed by deeper recessions and slower recoveries of key macroeconomic variables.

In the postwar period in the United States, movements in house prices until 2000 can be explained by increases in housing quality and construction costs (1950-70) or regulatory restrictions (1979-95). These facts are documented in Poterba (1984), Himmelberg, Mayer, and Sinai (2005), Shiller (2007), Glaeser, Gyourko, and Saks (2005), and Chambers, Garriga, and Schlagenhauf (2016). During this period, the interaction between housing markets and macroeconomic aggregates was limited, as aggregate house prices always grew in real terms. 


\section{Famiglietti, Garriga, Hedlund}

In the 2000s, the boom-bust was fueled by an expansion and subsequent contraction of the credit supply along with changing expectations about future house price appreciation. $\frac{2}{2}$ For example, Campbell et al. (2009) find that for the period 1997-2007, movements in pricerent ratios can be attributed more to time variation in the housing premium and less to expectations of future rent growth. The collapse of the housing market and the implications for the macroeconomy, in particular aggregate employment and consumption, has been a growing research topic. Boldrin et al. (2013) use a dynamic multisector model with production linkages where a decline in housing demand propagates through the rest of the economy, thereby reducing aggregate output and employment. Garriga, Manuelli, and Peralta-Alva (2019) develop a macroeconomic model of market segmentation that generates sizable movement in house values driven by current and future credit conditions. The endogenous collapse of house prices induces a large and persistent recession through the deleveraging process and decline in aggregate consumption. In addition to debt deleveraging, large declines in house values also generate a large negative wealth effect that propagates to aggregate consumption (i.e., Iacoviello and Pavan, 2013; Huo and Ríos-Rull, 2016; and Berger et al., 2017).

The collapse of the housing market can also spill over to the credit market in the form of a spike in mortgage delinquencies and foreclosures, such as occurred during the Great Recession (see Mian and Sufi, 2009; Anenberg and Kung, 2014; and Mian, Sufi, and Trebbi, 2015). These issues have also received attention in the macro structural literature. The complexity of the problem often requires that house prices be exogenous in the model, to allow study of the determinants of mortgage default (see Guler, 2015; Corbae and Quintin, 2015; Campbell and Cocco, 2015; Hatchondo, Martinez, and Sanchez, 2015; and Geraradi et al., 2018). Other papers explore the spillover effects of foreclosure on house prices by making both objects endogenous (i.e., Garriga and Schlagenghauf, 2009; Chatterjee and Eyigungor, 2015; and Arslan, Guler, and Taskin, 2015).

One of the challenges for this literature is to acknowledge that periods with large declines in house values also coincide with an impaired ability to transact housing units, particularly for sellers. ${ }^{3}$ In short, the magnitude and duration of these crises partially depend on the decline and recovery of housing liquidity. These issues have been documented and formalized using a structural general equilibrium model, including by Hedlund (2016 and 2018) and Garriga and Hedlund (2018 and 2019). Their analysis suggests that the deterioration in house prices and liquidity - transmitted to consumption via balance sheets that vary in composition and depth-is central to explaining the observed aggregate and cross-sectional patterns of macro and housing variables. More specifically, large declines in housing liquidity in an area are correlated with declines in house prices and macroeconomic conditions in that area.

\section{DATA DESCRIPTION}

To study the relationship among housing, credit, and macroeconomic conditions, this article uses transaction-level data from the Multiple Listing Services ${ }^{\circledast}$ (MLS) from CoreLogic, individual-level credit data from the Federal Reserve Bank of New York Consumer Credit Panel based on Equifax credit report data (FRBNY CCP/Equifax), and adjusted gross income 
Famiglietti, Garriga, Hedlund

\section{Table 1}

\section{National Summary Statistics (2006-11)}

\begin{tabular}{|c|c|c|c|c|c|c|}
\hline & Obs. & Mean & SD & 10th & Median & 90th \\
\hline Income $(\% \Delta)$ & 9,356 & -6.3 & 11.1 & -15.8 & -5.9 & 1.7 \\
\hline House prices $(\% \Delta)$ & 9,425 & -33.4 & 20.9 & -61.4 & -32.6 & -6.7 \\
\hline Months' supply ( $\Delta$ Months) & 9,425 & 3.1 & 7.4 & -3.7 & 3.1 & 10.5 \\
\hline TOM ( $\triangle$ Days) & 9,425 & 47.4 & 35.2 & 9.8 & 42.5 & 93.6 \\
\hline Mortgage delinquency rate $(\Delta p p)$ & 9,410 & 4.7 & 4.4 & 0.8 & 3.3 & 10.5 \\
\hline
\end{tabular}

NOTE: The table reports ZIP-code-level statistics. Obs., observations. SD, standard deviation. 10th, 10th percentile. 90th, 90th percentile. $\mathrm{pp}$, percentage points.

SOURCE: Income: IRS SOI deflated by personal consumption expenditures (PCE). House prices, months' supply, TOM: CoreLogic's MLS. House prices are deflated by PCE. Mortgage delinquency rate: FRBNY CCP\Equifax.

(hereafter income) data from the Internal Revenue Service (IRS) measured at the ZIP code level. In addition to the closing price and date, the MLS dataset contains the listing date, asking price, and property location. Because the data are at the listing level, both failed and successful listings are observed, making it possible to track whether a seller delists and relists a house (for example, to move up the queue of online search results). The coverage of the MLS is broad, covering approximately 74 percent of the U.S. population in 2006 (16,954 ZIP codes) and over 85 percent of the population (20,109 ZIP codes) in 2011. The analysis of the housing variables is restricted to single-family homes and condominiums. The credit variables track several measures of mortgage payment status: delinquent, seriously delinquent, and "severely derogatory" loans (see the appendix for further details). We define the mortgage delinquency rate as the ratio of the total number of all three of these statuses to the outstanding number of mortgages. The FRBNY CCP/Equifax and MLS data are aggregated to the ZIP code level for comparison in many of the analyses that follow. For macroeconomic conditions, the IRS data provide detailed information of income at the ZIP code level as well as distributions across different brackets and the number of individuals filling. The analysis uses the mean value in every ZIP code. Table 1 provides national summary statistics for these variables during the period 2006-11. ${ }^{ \pm}$Table 2 provides regional mean statistics for the individual most-adverse time windows from 2005-2012 for the three regions studied.

The statistics in Table 1 illustrate the depth and duration of the Great Recession's impact on housing markets nationally. House prices in the MLS data declined on average over 33 percent, which is consistent with broad house price indices based on repeated sales, such as the Federal Housing Finance Agency and S\&P/Case-Shiller indices. Table 2 reveals that declines in house prices were more severe in California and the Sunbelt states: All experienced declines larger than the national average. As shown in Table 1 for the nation, the magnitude of the decline for the bottom of the distribution was particularly large, with some ZIP codes experiencing house price declines in excess of 60 percent. Contemporaneously, the average days needed to sell a house, that is, the TOM, increased 40 percent, from 117 days to 164 days. The size of the increase is symmetric, with a 39 percent increase in the bottom 10th percentile and 


\section{Table 2}

\section{Regional Summary Statistics (Mean Values)}

\begin{tabular}{lccc} 
& California (2005-09) & Sunbelt (2005-11) & Other (2006-10) \\
\cline { 2 - 4 } Income $(\% \Delta)$ & -5.2 & -15.2 & -3.0 \\
\hline House prices $(\% \Delta)$ & -47.7 & 51.7 & -20.1 \\
\hline Months' supply $(\Delta$ Months) & 3.0 & 5.2 & 5.4 \\
\hline TOM $(\Delta$ Days) & 42.1 & 92.9 & 34.8 \\
\hline Mortgage delinquency rate $(\Delta \mathrm{pp})$ & 9.3 & 9.8 & 3.1 \\
\hline
\end{tabular}

NOTE: The table reports ZIP-code-level statistics. Sunbelt, the Sunbelt states of Arizona, Nevada, and Florida. Other, all other states. pp, percentage points.

SOURCE: Income: IRS SOI deflated by PCE. House prices, months' supply, TOM: CoreLogic's MLS. House prices are deflated by PCE. Delinquency rates: FRBNY CCP\Equifax.

41 percent increase in the top 90th percentile. Units that used to sell twice as fast as the national average became very illiquid during the Great Recession.

The comparison of the national statistics with the regional statistics reveals the housing crisis was more severe in specific regions of the United States. In particular, comparing the average mortgage delinquency rates of California and the Sunbelt states at the height of their local crises with those in the 90th percentile of the national statistics demonstrates that these regions were far more adversely affected by the housing crisis than most regions. As a counterfactual, Table 2 includes a column for all other states in their most adverse period. At their worst, the other states experienced only a 3.1 percent increase in the mortgage delinquency rate, confirming that a large portion of delinquent mortgages were concentrated in California and the Sunbelt states.

The findings of Table 2 demonstrate that the housing crisis had heterogeneous effects across regions that would be missed when looking at national statistics. National statistics show a large increase in housing market illiquidity, a decline in real house prices and incomes, and an increase in mortgage delinquency rates. However, these effects were not uniform. In California, house prices declined by more than the national average and the mortgage delinquency rate increased by far more than the national average, while housing liquidity and income declined by less than the national averages. In the Sunbelt states, income declined a staggering 15.2 percent, TOM increased to nearly 93 days (almost double the national average), and the mortgage delinquency rate increased nearly 10 percent. All other states experienced a recession, with income decreasing 3 percent and house prices falling near 20 percent, but conditions did not deteriorate to the extent witnessed in the Sunbelt states.

These trends are also evident in heat maps. Specifically, Figure 1 plots percent changes in house prices and income and mortgage delinquency rates by ZIP code. The period used is 2006-2011, to reflect the national statistics and to show that, although Table 2 reports specific time windows for the highlighted regions, the general findings do not change materially when using the same period across regions. It is evident that house prices deteriorated the most in 


\section{Figure 1}

\section{Macroeconomic Conditions During the Great Recession}
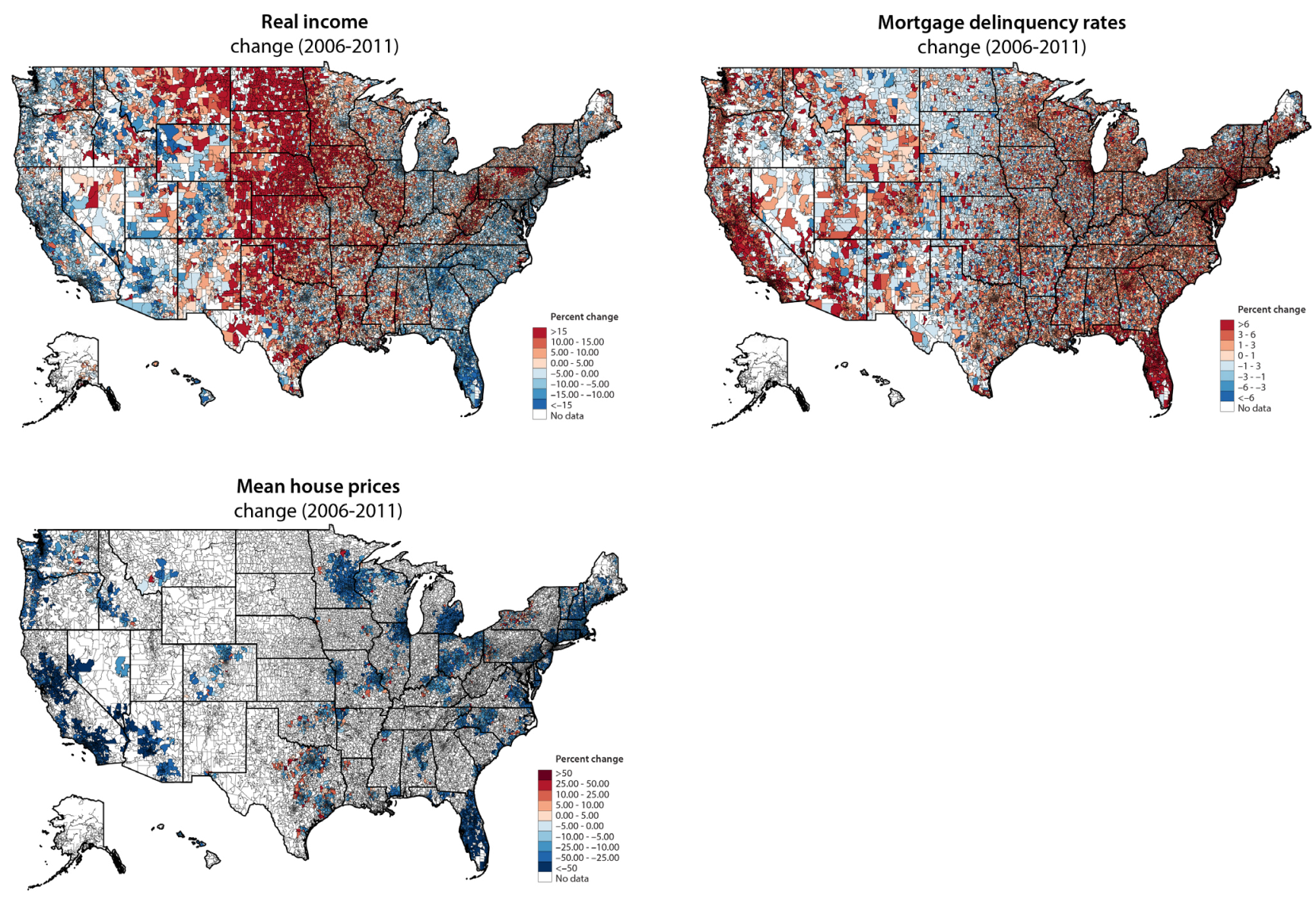

SOURCE: Income: IRS SOI. Mortgage delinquency rates: FRBNY CCP\Equifax. House prices: CoreLogic's MLS.

metropolitan areas in California, Arizona, Florida, and Nevada (especially Las Vegas).

Furthermore, these plots show house prices had not recovered by 2011, a full two years after the end of the recession. These same areas also seem to be where the mortgage delinquency rate increased most dramatically, with Florida a particularly stark case (see Figure 1). The depth of the recession in these areas becomes most clear when comparing the maps of house prices and mortgage delinquency rates to that for income. By 2011, many areas in the country such as Texas and large swaths of the South and Midwest had fully recovered and income exceeded 2006 levels. The areas where the housing markets deteriorated the most, such as California and the Sunbelt states of Arizona, Nevada, and Florida, had lower real incomes in 2011 than they had in 2006.

It is convenient to explore two complementary measures of housing liquidity over time. One is TOM, the number of days between listing a property and selling a property. As such, 
Figure 2

Housing Liquidity During the Great Recession
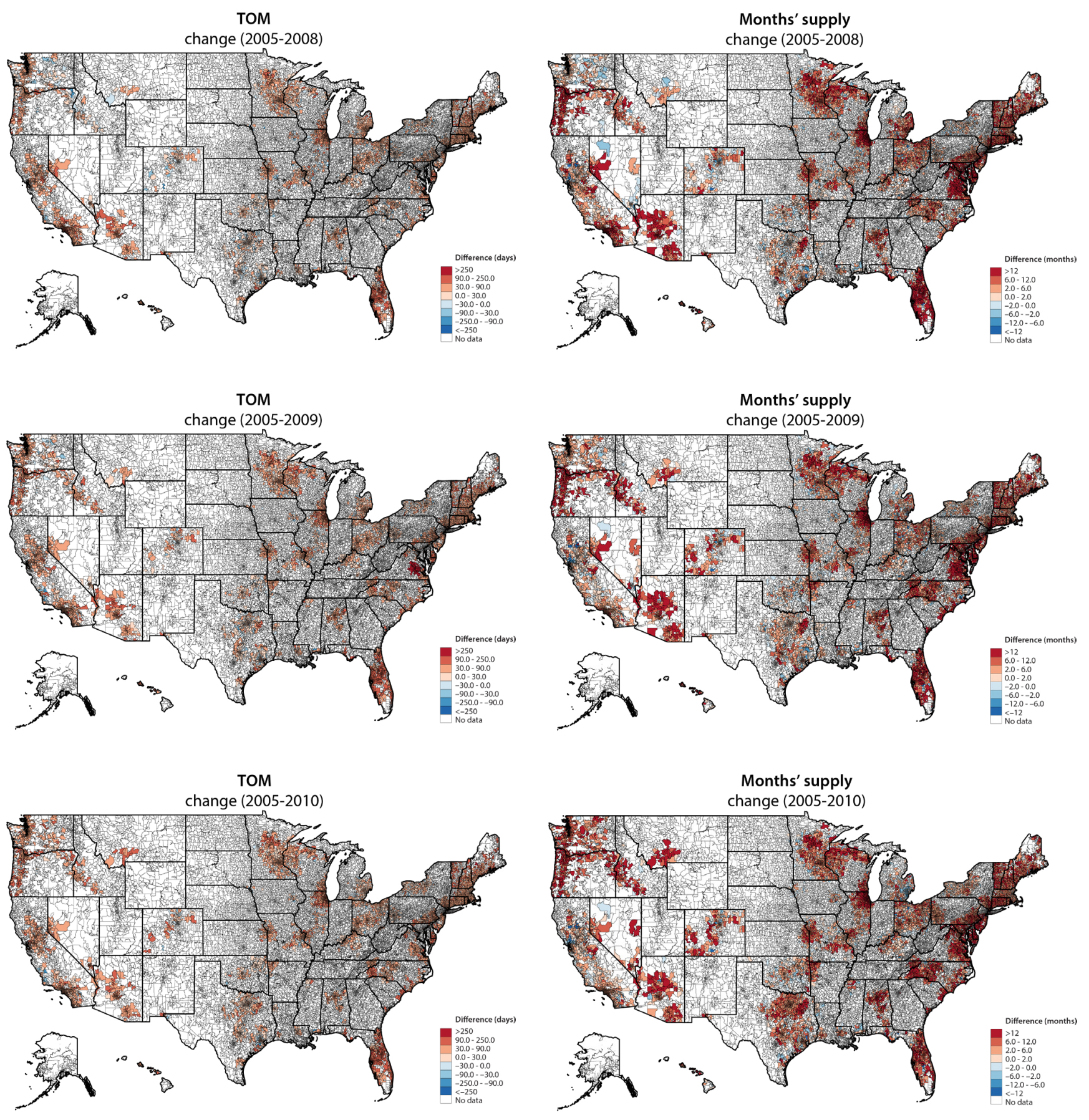

SOURCE: TOM, months' supply: CoreLogic's MLS. 
this liquidity measure is constructed from individual transactions. The other is months' supply, a market-level measure of housing liquidity that comes from dividing the stock of unsold listings by the number of houses sold in a given geography and month. To be consistent with

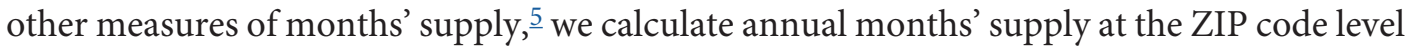
by averaging over each year the monthly measures calculated from the MLS. ${ }^{6}$ Whether using TOM or months' supply, analyzing housing liquidity shows that, analogously to house prices, the national housing market did not recover to pre-recession levels until well after the Great Recession.

The heat maps in Figure 2 illustrate how measures of liquidity evolved in specific ZIP codes over time and reveal that national housing market conditions remained depressed during the Great Recession and beyond. The left-hand panels show the evolution of TOM and the right-hand panels the evolution of months' supply.

Measures of illiquidity remained elevated for at least five years after the initial housing bust. Nationally, this corresponded to about an additional month to sell a house or more than an additional three months' supply of housing stock. A reduction in housing liquidity during this period is critical to understanding the housing crisis because the inability to sell homes significantly worsened national macroeconomic conditions, as indicated by the regressions in Section V. These trends further demonstrate the heterogeneous effect the housing crisis had on regions in the United States, with California and the Sunbelt states having more illiquid markets earlier in the crisis.

\section{CHANGES IN HOUSING LIQUIDITY WITHIN LOCAL MARKETS}

An important issue is whether the composition of housing units for sale in the market had different characteristics or qualities during the Great Recession relative to the boom period. To address this issue, this section provides additional evidence of the change of housing liquidity within each regional market.

For the period 2005-11, the density of TOM for the nation, California, the Sunbelt states, and all other states are depicted in Figure 3. The national plot suggests that liquidity reached its worst levels between 2008 and 2011. However, the regional plots suggest that this was not a uniform trend. California and the Sunbelt states experienced significant rightward shifts in their liquidity distributions earlier in the crisis, primarily in 2007 and 2008. The other regions did not display liquidity changes of those magnitudes until the later years of the crisis, such as 2011. Interestingly, California and the Sunbelt states saw a partial recovery in housing liquidity by 2009 and 2011, respectively. In contrast, the other regions of the United States largely saw slower liquidity declines during this period, but the declines were generally monotonic, with the worst years for housing liquidity occurring between 2008 and 2011.

Besides the temporal differences in these distributions of liquidity, the magnitudes of the changes in liquidity density varied across regions. The Sunbelt states experienced a more severe shock than the rest of the nation-including California. California experienced an early shock to liquidity, but its TOM measure never reached that for the Sunbelt states and its TOM measure recovered more quickly. Analyzing the levels of housing liquidity is useful 


\section{Figure 3}

\section{Housing Liquidity Kernel Density Plots (TOM, 2005-11)}
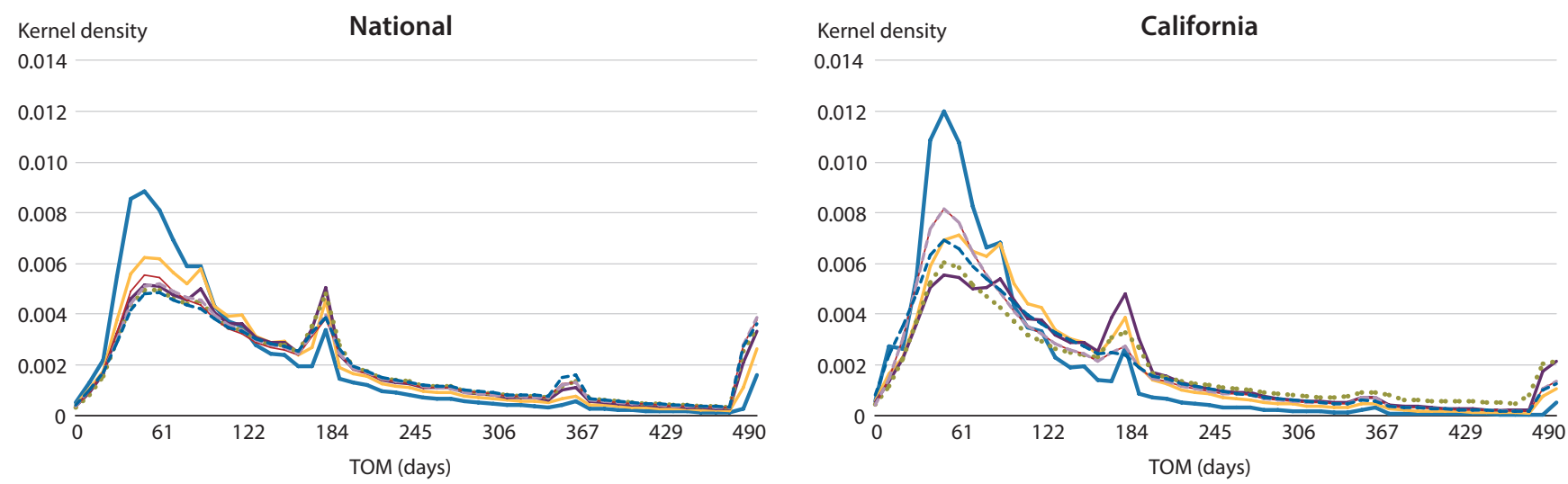

Kernel density

Sunbelt
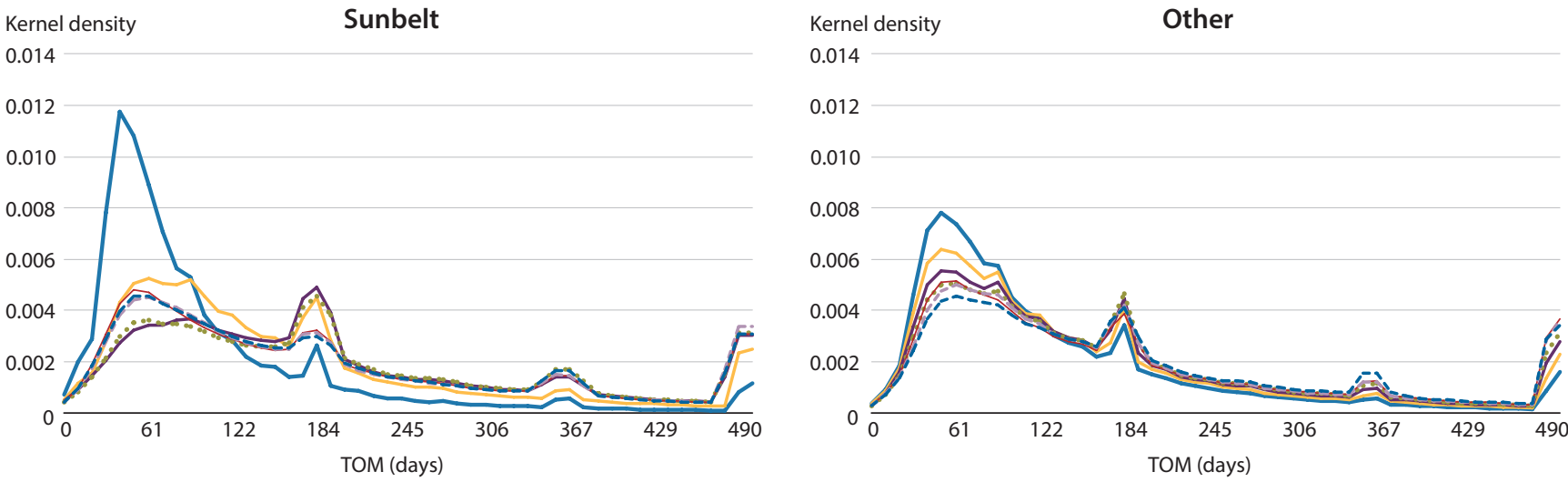

-2005-2006 -2007 $\quad \ldots 2008 \quad-2009 \quad--2010 \quad---2011$

NOTE: Sunbelt, the Sunbelt states of Arizona, Nevada, and Florida. Other, all other states. The right tail is truncated at 490 days on the market. Any value over this threshold is included in the tail. Kernel density plots of housing liquidity (2005-11).

SOURCE: CoreLogic's MLS.

insofar as it can differentiate relatively liquid and illiquid regional housing markets. A factor that made the housing crisis particularly severe in California and the Sunbelt states was the change in liquidity during this period. In 2005, a larger portion of the homes in these regions were selling in under three months compared with the other regions of the United States (see Figure 3). The liquidity shocks of the housing crisis caused larger percentage reductions in liquidity in these regions compared with the rest of the United States.

To measure statistically how liquidity changed over time, we calculate measures of statistical significance and uniformity in trends; more specifically, we use a Kolmogorov-Smirnov test. The test is performed on all the density distributions, finding them all statistically different and significant at the 1 percent level. Across all regions, the number of homes sold in under three months dramatically decreased from 2005 levels. Starting in 2006, liquidity decreased 


\section{Figure 4}

\section{TOM Distributions (2000-16)}
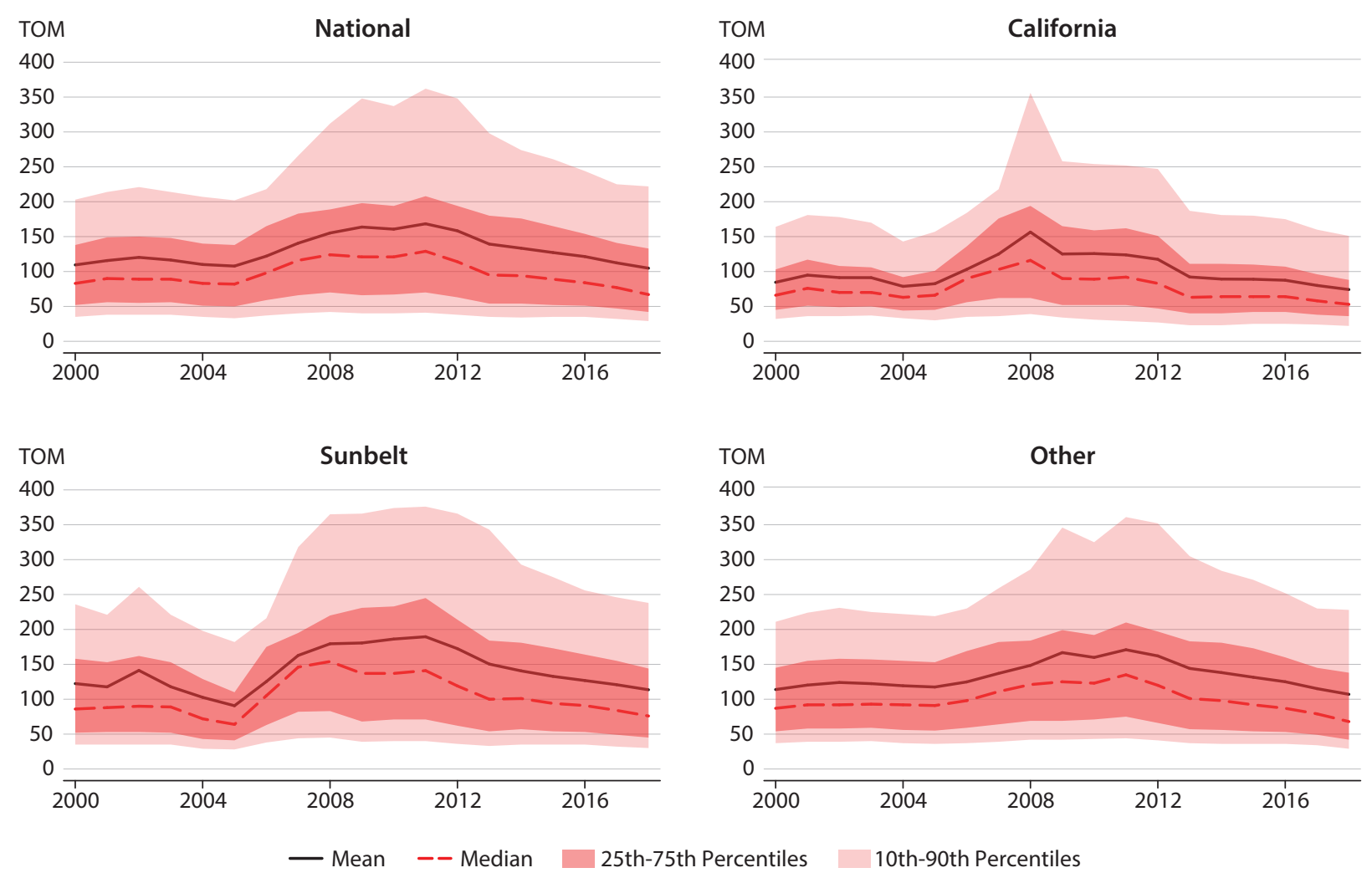

NOTE: Sunbelt, the Sunbelt states of Arizona, Nevada, and Florida. Other, all other states.

SOURCE: CoreLogic's MLS.

in all housing markets, but the timing and height of the peak of housing illiquidity varies among regions.

In addition to regional effects, we analyze how segments of housing markets within regions responded to the liquidity shock of the Great Recession. In particular, it is important to determine whether the housing crisis caused already hard-to-sell homes to become more illiquid or if it impacted all houses uniformly. Figure 4 plots the mean, median, 25th-75th percentile, and 10th-90th percentile measures of TOM for each of the regions over time. Plotting the percentiles of the housing market captures how different local markets responded to the housing crisis and whether there were composition effects that account for the trends, such as illiquidity build-ups in specific segments of the market.

As shown in Figure 4, there were little to no composition effects in determining the trends in liquidity during this period. The different percentiles of the housing market in each region received negative liquidity shocks at approximately the same time and experienced similar percent declines in liquidity levels. 


\section{Figure 5}

\section{House Price Distributions Deflated by Personal Consumption Expenditures (2000-16)}
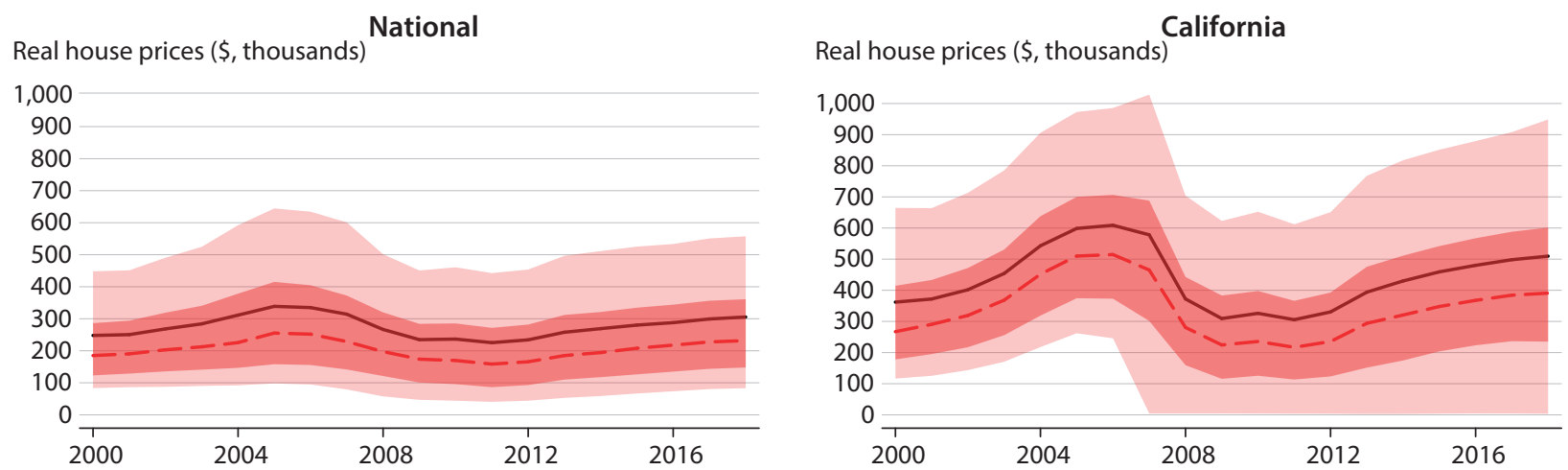

Real house prices ( $\$$, thousands) Sunbelt
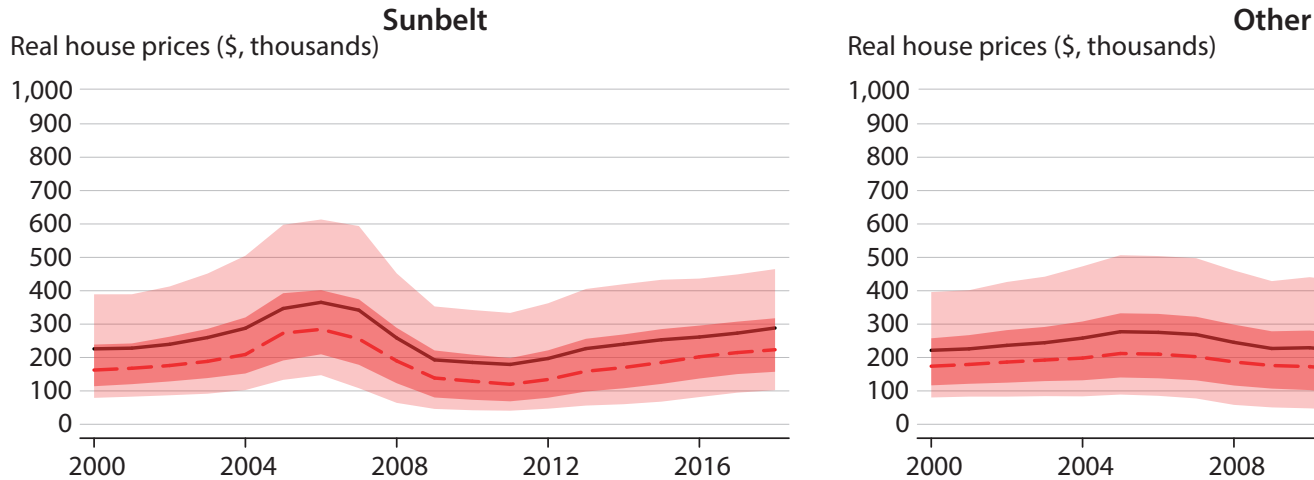

1,000

900

800

700

600

500

400

300

200

100

0 2000

house prices (\$, thousands)
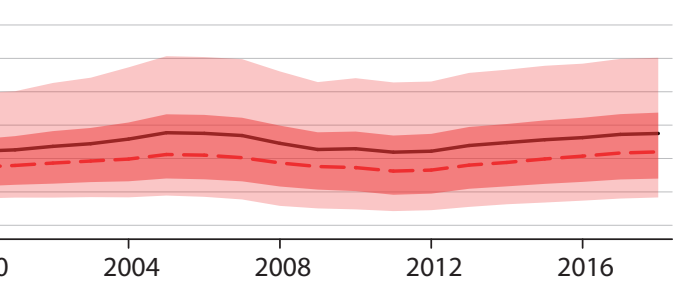

- Mean $\quad--$ Median $\quad$ 25th-75th Percentiles 10th-90th Percentiles

NOTE: Sunbelt, the Sunbelt states of Arizona, Nevada, and Florida. Other, all other states.

SOURCE: CoreLogic's MLS.

As discussed by Mian and Sufi (2009), the vast majority of housing markets saw severe price declines during the Great Recession. A reasonable question is whether the widespread collapse had uneven effects on different tiers of the housing market. To address this issue, Figure 5 plots different moments (namely, the mean, median, 25th-75th percentiles, and 10th-90th percentiles) of the distribution of real house prices in each region over time. Across all regions, a negative shock occurs starting in 2005, 2006, or 2007, depending on the region. In a manner analogous to liquidity, the timing, levels, and severity of the declines in house prices vary greatly across regions. California and the Sunbelt states saw the earliest and steepest declines in house prices. Furthermore, California experienced a recovery in house prices years earlier than the rest of the nation. Figure 5 also suggests that national house prices had yet to recover to their pre-2005 levels a full decade after the start of the crisis. For the Sunbelt states, the decline in real house prices persisted long after the crisis and did not begin to recover until more than five years after the official end date of the Great Recession. 


\section{Figure 6}

\section{ZIP Code Correlations of House Prices, Income, and Mortgage Delinquency Rates}

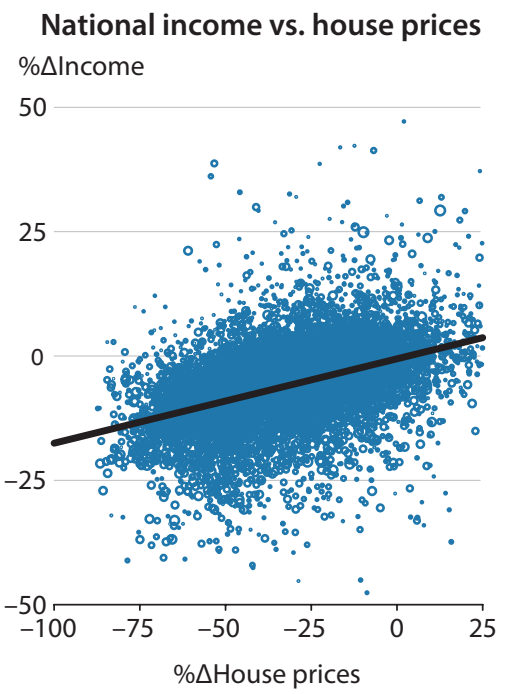

National MDRs vs. house prices

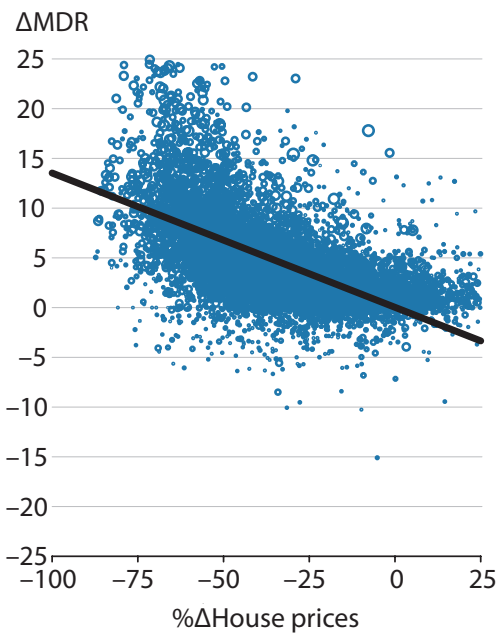

California income vs. house prices $\% \Delta$ Income

50

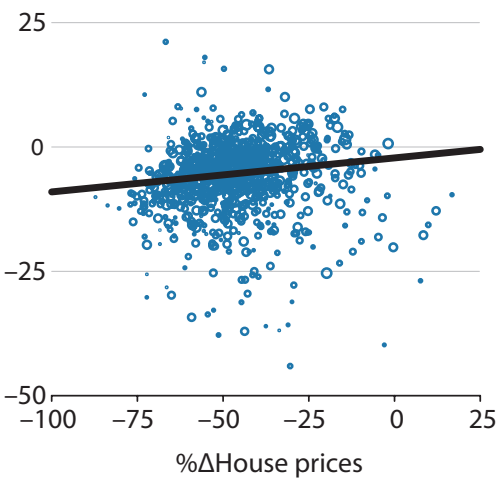

California MDRs vs. house prices $\triangle M D R$
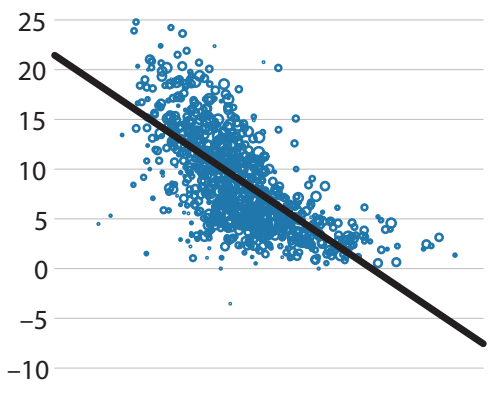

$-15$

$-20$

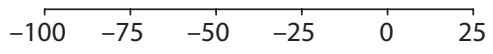

Sunbelt income vs. house prices $\% \Delta$ Income

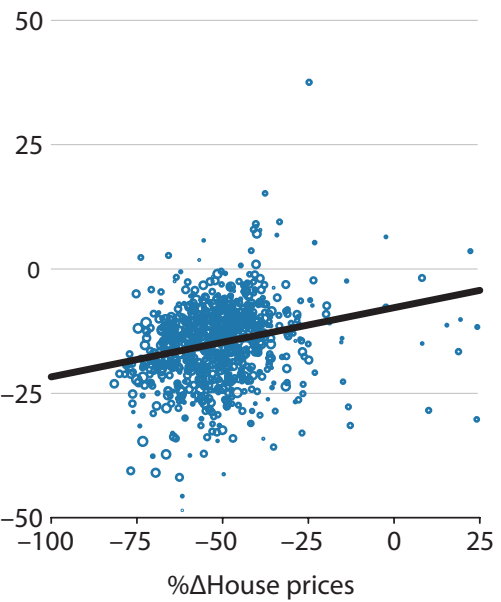

Sunbelt MDRs vs. house prices $\triangle M D R$

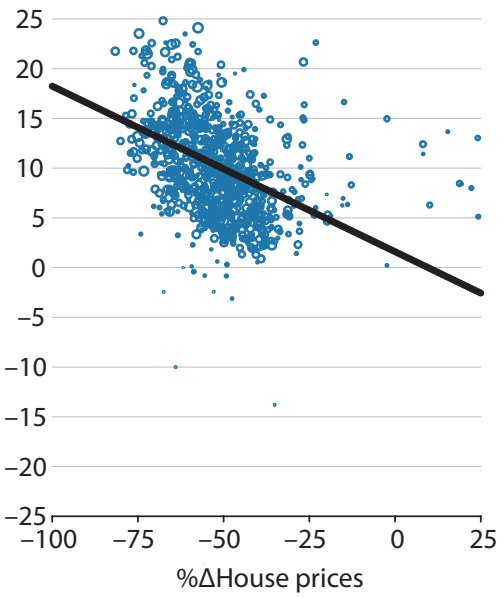

NOTE: MDR, mortgage delinquency rate. Sunbelt, the Sunbelt states of Arizona, Nevada, and Florida. The periods used are 2006-11, 2005-09, and 2005-11, respectively, for the nation, California, and the Sunbelt. These periods were chosen to reflect the most consistently adverse time windows for each region from a housing perspective. Correlations are weighted by population of the start year. Each bubble is an individual ZIP code, where the diameter is indicative of population.

SOURCE: House prices: CoreLogic's MLS. Mortgage delinquency rates: FRBNY CCP\Equifax. Income: IRS SOI. 


\section{Figure 7}

\section{ZIP Code Correlations of TOM, Income, and Mortgage Delinquency Rates}
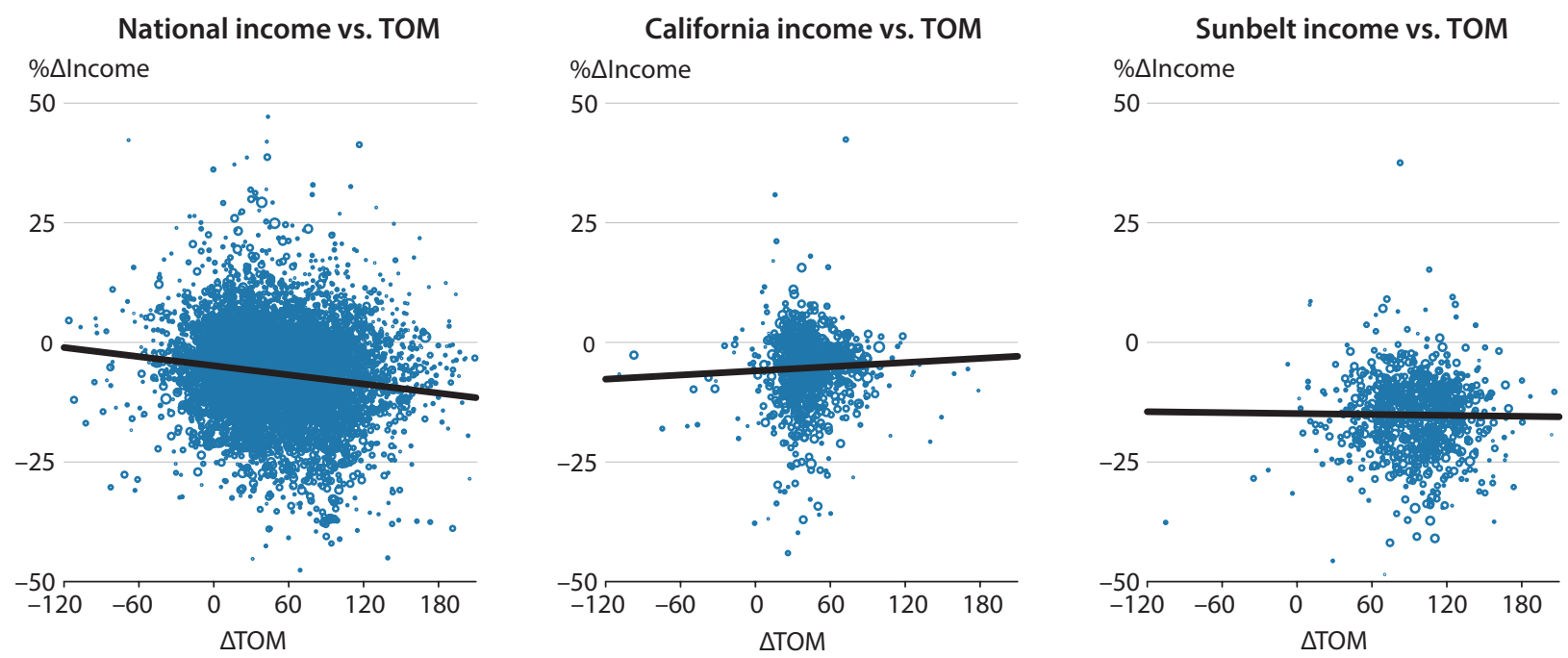

\section{National MDRs vs. TOM}

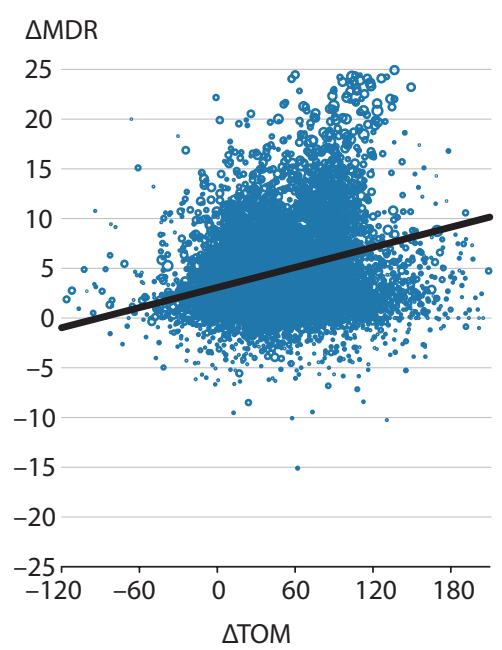

\section{California MDRs vs. TOM}

$$
\triangle \mathrm{MDR}
$$
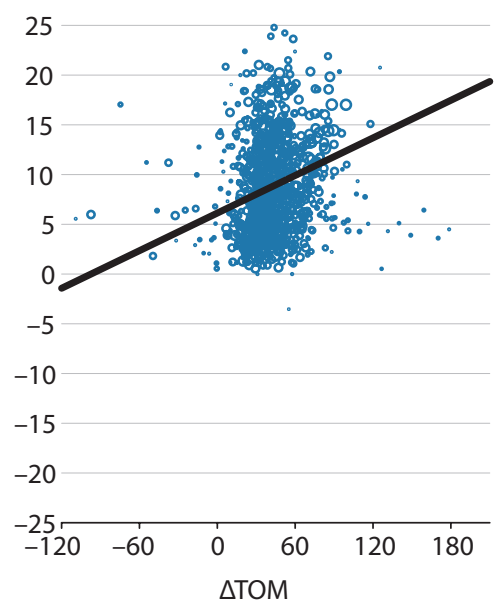

Sunbelt MDRs vs. TOM

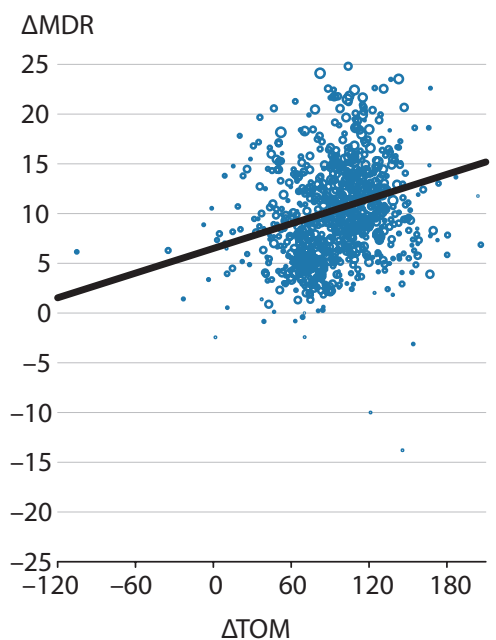

NOTE: Sunbelt, the Sunbelt states of Arizona, Nevada, and Florida. MDR, mortgage delinquency rate. The periods used are 2006-11, 2005-09, and 2005-11, respectively, for the nation, California, and the Sunbelt. Correlations are weighted by population of the start year. Each bubble is an individual ZIP code, where the diameter is indicative of population.

SOURCE: TOM: Corelogic's MLS. Mortgage delinquency rates: FRBNY CCP\Equifax. Income: IRS SOI. 
While the magnitudes of house price changes vary across housing tiers (see Armesto and Garriga, 2009, for a more detailed analysis across U.S. cities for the period 1995:Q3-2009:Q3), the figure illustrates relatively uniform patterns across the different percentiles of the distributions. The aggregate housing price decline impacted the bottom quartile (which includes starter homes) as well as the top quartile of the housing stock (which includes luxury homes). Similar patterns emerge across all tiers of the regional housing markets. The timing of the decline of house prices across tiers is strikingly uniform and points to a truly macroeconomic shock to prices. In other words, during these episodes, when the aggregate, national price moved, all segments of the housing market changed.

The performance of housing markets is also connected to macroeconomic developments at a granular level. This point has been empirically made by Mian and Sufi (2014) and more formally, using structural models, by Boldrin et al. (2013); Herkenhoff and Ohanian (2019); and Garriga and Hedlund (forthcoming), who emphasize housing liquidity. The scatter plots of Figure 6 demonstrate that the shock to house prices in 2006 was correlated with outcomes in the macroeconomy (income) and the credit market (the mortgage delinquency rate).

Nationally, at the ZIP code level, income and house prices are correlated with a coefficient of approximately 0.40 . This relationship weakens somewhat for specific regions but still exists for California and the Sunbelt states. The relationship between mortgage delinquency rates and house prices is consistent across all regions and has a coefficient of -0.53 for the nation. This implies that the housing market shocks shown had potentially large spillovers on the U.S. economy during this period.

The performance of the local housing market is described both by the dynamics of house prices and the behavior of housing liquidity. In the data, housing liquidity proves to be an important factor determining the impact housing markets had on macroeconomic outcomes such as income.

Figure 7 plots by ZIP code for the nation, California, and the Sunbelt states the changes in TOM (liquidity) relative to changes in income and the mortgage delinquency rate, respectively. At the national level, there is a weakly negative relationship between the changes in liquidity and income during the crisis period. This relationship is consistent with the predictions of the structural model in Garriga and Hedlund (2019). At a more disaggregated level, the sign of the correlation varies by region and once we add additional controls, as in Section V, the results are more consistent with the national correlation. Similarly, the correlation coefficient of mortgage delinquency rates and liquidity at the national level is 0.15 , representing a decline from that of house prices and mortgage delinquency.

The heterogeneity of these regional relationships is notable. Nationally, changes in house prices and liquidity appear nearly uncorrelated, as they have a correlation coefficient of merely -0.01 . However, California exhibits a stronger negative relationship for this measure, with a correlation coefficient of -0.05 , implying it had a number of areas where liquidity increased and house prices decreased, the expected relationship predicted in Garriga and Hedlund (forthcoming). For the Sunbelt states, the correlation coefficient is 0.10, implying they had some places where prices and liquidity moved together. These correlations highlight the regional variation in housing market relationships during the period. We explore a potential explanation of this heterogeneity in Section V. 


\section{V.HOUSING LIQUIDITY, GEOGRAPHY, AND MACRO PERFORMANCE}

To more formally establish the statistical significance of housing liquidity on macroeconomic variables during the Great Recession, we perform a series of regression analyses in the same spirit of Mian et al. (2013) and Mian and Sufi (2014). The basic idea is to explore how the addition of measures of housing liquidity improves the understanding of the channels that connect housing markets and the broader economy. Changes in housing liquidity depress housing demand, but decreased liquidity is ultimately correlated with negative macroeconomic performance. The advantage of using granular data is that it allows capture of measures of housing liquidity in finer terms.

The regressions use ZIP-code-level data from the MLS for house prices and liquidity, FRBNY CCP/Equifax for mortgage delinquency rates, and the IRS statistics of income (SOI) for income. MLS data are the result of manual entry by listing and selling agents, so mistakes and outliers can occur. To correct for this, we winsorize the top and bottom 10 percent of the liquidity change measures. This method allows us to preserve large values, which are plausible given the severity of the housing crisis, but corrects for extreme outliers and data errors.

The basic model of the regressions in this section uses ordinary least squares, with observations weighted by population calculated as the number of tax returns in a ZIP code in the IRS SOI data. We choose 2006 as the year for the weights, but this is arbitrary. The IRS SOI data consistently provide exceptional coverage of the United States, so choosing a specific year does not reduce the number of observations. Furthermore, the number of tax returns (the proxy used for population) is stable over time and approximates the cardinal ranking of ZIP codes by population.

The model form is given by

$$
\Delta \text { Outcome }_{t-(t-1)}^{i}=B_{0}+B_{1} \Delta \text { Liquidity }_{t-(t-1)}^{i}+B_{2} \Delta \text { HousePrice }_{t-(t-1)}^{i},
$$

where $\Delta \boldsymbol{O}$ utcome $\boldsymbol{e}_{t-(t-1)}^{i}$ is either the change in real income during the period or the change in the mortgage delinquency rate. The mortgage delinquency rate is calculated as noted above for each ZIP code. The change in mortgage delinquency and the change in income are each expressed as a percent change from the start to the end of the period. The change in liquidity is the number of days difference between the TOM at the start and the end of the period. The change in house prices is a percent change in real house prices from the start to the end of the period.

All regression models use the same periods for variables within regions, but as previously shown in Section III, the timing of house price and liquidity shocks varied across geographic regions. Therefore, each region uses a specific time window to reflect its housing crisis period: the nation, 2006-11; California, 2005-09; the Sunbelt states of Arizona, Nevada, and Florida, 2005-11; and all other ZIP codes, 2006-10. The results of these regressions for income and mortgage delinquency are found in Tables 3 and 4, respectively. As previously shown in Sections II and III, these windows are somewhat arbitrary, as regional housing markets were consistently adversely affected for the entirety of the sample period. 
For the time windows selected to approximate the regional troughs of the Great Recession, almost all the coefficients for both the changes in house prices and in housing liquidity are highly significant, economically sizable, and in the expected direction. For the national regression, with income as the dependent variable, a one-month increase in TOM is associated with approximately a 1 percent decline in real income, and a 10 percent decline in house prices is associated with approximately a 1.8 percent decline in real income. For the Sunbelt states, the liquidity effects are slightly larger; for California, the price effect is smaller and the liquidity effect is insignificant. To put these results into perspective, for the nation, the average decline in house prices was over 33 percent and the increase in TOM was 47.4 days, with the decline in house prices corresponding to an estimated -5.9 percent decline in income and the increase in TOM (decline in liquidity) to a -1.7 percent decline in income, for a total estimated decline in income of 7.6 percent for a representative ZIP code during 2006-11. The representative ZIP code saw its income actually decline 6.3 percent during this same period, so these estimates are in the historical range of income declines. The same decomposition yields estimated declines of 9.3 percent and 2.0 percent of income for house prices and liquidity, respectively, for the Sunbelt states (using the average declines in house prices and liquidity during this period). These simple regression models emphasize a strongly statistically and economically significant relation between housing variables and income.

When estimating the effects of the housing crisis on one specific indicator of housing market health - the mortgage delinquency rate-the effects are more dramatic. In this case, all variables are significant at the 1 percent level and in the expected direction. Even California has a strong correlation between the increase in TOM and the decline in house prices. For this region, a one-month increase in TOM is associated with a 2.0 percent increase in the mortgage delinquency rate. Between 2005 and 2009 in California, house prices declined 47.4 percent, TOM increased 42.1 days, and the mortgage delinquency rate increased from 0.3 percent to 9.7 percent. Using these averages, the regression in Table 4 estimates a 13.5 percent increase in mortgage delinquency. Analogous calculations for the Sunbelt states estimate a 17 percent increase in mortgage delinquency. Given the size and significance of both house prices and liquidity in the regional regression models, we conclude that both are critical factors to consider when estimating housing market outcomes.

The results of this empirical analysis strongly imply that house prices and liquidity were important factors for macroeconomic outcomes during the Great Recession. However, it should be noted this analysis uses ordinary least-square regression models that do not imply causality of the housing variables on the dependent variables used. These tests demonstrate that housing outcomes were highly correlated during this period with the decline in income and an increase in mortgage delinquency, but this analysis cannot say with any certainty to what extent the deterioration of housing markets caused the macroeconomic conditions experienced during the Great Recession, due to endogeneity of the dependent and independent variables. To more definitively state how much the illiquidity buildup of this period caused a decline in national income, some control for endogeneity would be required. 


\section{Table 3}

Regressions for Income with $\triangle A G I$ as the Dependent Variable (Number of Returns 2006 Weighted)

\begin{tabular}{lcccc} 
& National & California & Sunbelt & Other \\
\cline { 2 - 4 }$\Delta$ TOM & $-0.035^{* * *}$ & 0.026 & $-0.021^{*}$ & $-0.020^{* *}$ \\
& $(0.006)$ & $(0.016)$ & $(0.011)$ & $(0.008)$ \\
\hline \multirow{2}{*}{ Price } & $0.180^{* * *}$ & $0.055^{* * *}$ & $0.150^{* * *}$ & $0.079^{* * *}$ \\
Constant & $(0.008)$ & $(0.017)$ & $(0.021)$ & $(0.012)$ \\
\hline Observations & $1.966^{* * *}$ & $-3.767^{* * *}$ & $-5.232^{* * *}$ & -0.098 \\
\hline$R^{2}$ & $(0.422)$ & $(1.01)$ & $(1.685)$ & $(0.436)$ \\
\hline
\end{tabular}

NOTE: AGI, adjusted gross income. Sunbelt, the Sunbelt states of Arizona, Nevada, and Florida. Other, all other states. ZIP-code-level data have many outliers in the MLS. To control for these and limit their impact, the bottom and top 10 percent of changes in liquidity were winsorized. This applies to all regressions displayed in this article. Standard errors are in parentheses. Time windows for national, California, the Sunbelt, and other are 2006-11, 2005-09, 2005-11, and 2006-10, respectively. ${ }^{*} p<0.1,{ }^{* *} p<0.05$, and ${ }^{* * *} p<0.01$.

SOURCE: TOM, house prices: CoreLogic's MLS. Income: IRS SOI.

\section{Table 4}

Regressions for Mortgage Delinquency with $\triangle M D R$ as the Dependent Variable (Number of Returns 2006 Weighted)

\begin{tabular}{lcccc} 
& National & California & Sunbelt & Other \\
\cline { 2 - 4 }$\Delta$ TOM & $0.043^{* * *}$ & $0.066^{* * *}$ & $0.073^{* * * *}$ & $0.020^{* * *}$ \\
& $(0.001)$ & $(0.007)$ & $(0.006)$ & $(0.001)$ \\
\hline \multirow{2}{*}{ Price } & $-0.125^{* * *}$ & $-0.224^{* * *}$ & $-0.198^{* * *}$ & $-0.075^{* * * *}$ \\
\hline \multirow{2}{*}{ Constant } & $(0.002)$ & $(0.008)$ & $(0.011)$ & $(0.002)$ \\
\hline Observations & $-1.527^{* * *}$ & $-4.183^{* * *}$ & $-6.966^{* * *}$ & $1.039^{* * *}$ \\
\hline$R^{2}$ & $(0.083)$ & $(0.466)$ & $(0.892)$ & $(0.057)$ \\
\hline
\end{tabular}

NOTE: MDR, mortgage delinquency rate. Sunbelt, the Sunbelt states of Arizona, Nevada, and Florida. Other, all other states. Standard errors are in parentheses. Time windows for national, California, the Sunbelt, and other are 2006-11, 2005-09, 2005-11, and 2006-10, respectively. ${ }^{* * *} p<0.01$.

SOURCE: TOM, house prices: CoreLogic's MLS. Mortgage delinquency: FRBNY CCP\Equifax. 


\section{HOUSING LIQUIDITY AND HOUSING SUPPLY ELASTICITY}

The empirical analysis presented thus far has established that there were significant differences between regional housing markets during the Great Recession. Important questions to consider are these: What drove these regional differences, and why did the magnitudes of the house price and liquidity effects vary between regions? Obvious housing differences exist among California, the Sunbelt states, and many other regions of the United States. Perhaps the most notable regional housing difference is the age and amount of building development. Parts of California and the Sunbelt states are populated with relatively newly developed cities with broad city limits and an abundance of undeveloped land to use for future building. This regional feature differs from the older, more densely developed metropolitan areas in the Northeast. Possible explanations for the regional heterogeneity in response to the Great Recession are the differences in land availability and housing supply elasticity.

Even within the regions in this analysis, there is significant variation in local housing markets. Few would deny there are large land constraint and population density differences between San Francisco and San Bernardino counties. By grouping ZIP codes into geographic regions instead of categories based on some other economic similarity, our baseline analysis may be obscuring the effect of housing liquidity on macroeconomic outcomes. In particular, the variation of local housing supply elasticities is a natural candidate for grouping by ZIP code to analyze the responsiveness of the economy to shocks during the Great Recession. Saiz (2010) analyzes satellite footage of the United States to calculate housing supply elasticities based on land availabilities in MSAs. He finds that areas with little opportunity for land development due to land constraints were often the most housing supply inelastic. We use his MSA-level estimates of housing supply elasticity and assign an MSA-level value to each ZIP code found within a given MSA. We label ZIP codes in the highest quartile of elasticities (above 2.34) as "high elasticity" and in the lowest quartile (below 1.2) as "low elasticity."

It is well established in the literature that house prices respond more strongly to shocks in less-elastic markets. We would expect the same to be true for the response of housing liquidity. In particular, if housing demand increases and there is little ability to build new houses, prospective buyers will bid up prices and cause properties to sell more quickly. The reverse process would likely occur during a downturn, especially if it is assumed that house prices are sticky or that agents do not wish to sell their homes for a low price unless constrained to do so in cases such as bankruptcy. When homeowners are unlikely or unwilling to sell for low prices or are not required to do so, the time it takes to sell properties increases. This loss-aversion behavior in real estate markets has been documented in previous studies such as Genesove and Mayer (2001), and we expect it to affect low-elasticity markets. However, it is not yet known how local supply elasticity affects the transmission of changes in house prices and liquidity to macroeconomic and credit variables.

To test for heterogeneity in the housing transmission mechanism by the local supply elasticity, we re-estimate the model in equation (1) and group by elasticity rather than region. We estimate these regressions over the period 2005-11 to encompass the entirety of the national housing crisis. The results of the regressions are in Tables 5 and 6. 


\section{Table 5}

Saiz Elasticity Regressions for Income with $\triangle A G I_{05-11}$ as the Dependent Variable (Number of Returns 2006 Weighted)

\begin{tabular}{lccc} 
& National & High elasticity & Low elasticity \\
\cline { 2 - 4 }$\Delta$ TOM $_{05-11}$ & $-0.037^{* * *}$ & $-0.031^{* * *}$ & $-0.087^{* * *}$ \\
& $(0.003)$ & $(0.008)$ & $(0.006)$ \\
\hline Price $_{05-11}$ & $0.195^{* * *}$ & $0.127^{* * *}$ & $0.194^{* * *}$ \\
\hline \multirow{2}{*}{ Constant } & $(0.004)$ & $(0.008)$ & $(0.010)$ \\
\hline Observations & $2.703^{* * *}$ & -0.256 & $6.402^{* * *}$ \\
\hline$R^{2}$ & $(0.222)$ & $(0.388)$ & $(0.581)$ \\
\hline
\end{tabular}

NOTE: AGI, adjusted gross income. Elasticity groups are given in the column headers. Standard errors are in parentheses. *** $p<0.01$.

SOURCE: TOM, house prices: CoreLogic's MLS. Mortgage delinquency: FRBNY CCP\Equifax. Income: IRS SOI. Saiz elasticities: Saiz (2010).

\section{Table 6}

Saiz Elasticity Regressions for Mortgage Delinquency Rates with $\Delta M D R_{05-11}$ as the Dependent Variable (Number of Returns 2006 Weighted)

\begin{tabular}{lccc} 
& National & High elasticity & Low elasticity \\
\cline { 2 - 4 }$\Delta$ TOM $_{05-11}$ & $0.044^{* * *}$ & -0.001 & $0.071^{* * *}$ \\
& $(0.001)$ & $(0.002)$ & $(0.003)$ \\
\hline Price $_{05-11}$ & $-0.107^{* * *}$ & $-0.039^{* * *}$ & $-0.170^{* * *}$ \\
& $(0.002)$ & $(0.002)$ & $(0.005)$ \\
\hline \multirow{2}{*}{ Constant } & $-1.215^{* * *}$ & $1.384^{* * *}$ & $-4.772^{* * *}$ \\
\hline Observations & $(0.097)$ & $(0.110)$ & $(0.295)$ \\
\hline$R^{2}$ & 6,146 & 1,643 & 1,521 \\
\hline
\end{tabular}

NOTE: MDR, mortgage delinquency rate. Elasticity groups are given in the column headers. Standard errors are in parentheses. ${ }^{* * *} p<0.01$.

SOURCE: TOM, prices: CoreLogic's MLS. Mortgage delinquency: FRBNY CCPIEquifax. Income: IRS SOI. Saiz elasticities: Saiz (2010). 
For ZIP code MSAs with an inelastic housing supply, a one-month increase in TOM yields an estimated 2.6 percent decline in income, and a 10 percent decline in house prices yields an estimated 1.9 percent decline in income. At the national level, the estimated declines are a 1.1 percent and 1.9 percent, respectively. Thus, the housing transmission mechanism for both prices and liquidity to income is stronger in low-elasticity areas. By contrast, in high-elasticity areas, a one-month increase in TOM yields only an estimated 0.9 percent decline in income, and a 10 percent decline in house prices only an estimated 1.3 percent decline in income.

Switching focus to the mortgage delinquency rate, the results are similarly stronger in lowelasticity areas. Specifically, a one-month increase in TOM yields an estimated 2.1-percentagepoint increase in the mortgage delinquency rate compared with no statistically significant effect in high-elasticity areas and a 1.3-percentage-point increase nationwide. The price effect is also strongest in low-elasticity areas. The lesson that emerges by comparing Tables 3 and 4 with Tables 5 and 6 is that grouping by elasticity shows starker differences in the transmission from housing to the rest of the economy than does grouping by geographic region.

\section{CONCLUSION}

The empirical findings in this article demonstrate that there was significant variation in the timing and magnitude of the housing market collapse across the United States. The more disaggregated analysis at the transactional and ZIP code level relative to previous studies at the county level indicates that, in addition to house prices, housing liquidity was strongly associated with the deterioration of macroeconomic outcomes during this period. Grouping the United States into areas of low and high elasticity of the housing supply confirms that the magnitude of the effect of liquidity is at least partially dependent on characteristics of local housing markets. 


\section{APPENDIX: DATA SOURCES}

\section{MLS Data}

The MLS data are part of the CoreLogic Real Estate Database in the RADAR Data Warehouse (DW), which contains property-level data on deed and mortgage transactions, foreclosure actions, tax assessors' characteristics, and sale listings for residential properties around the United States. The MLS data include listings for properties that are on the market for sale or for rent. The data come from real estate boards, organizations of real estate agents who enter properties into an electronic MLS system in order to market them. The focus of our analysis is properties for sale, so we drop the rental properties information. The data include a large array of fields but most fundamentally cover things such as the date the property went on the market; the asking price; and a description of the properties features such as the square footage of living area, the number of bedrooms and bathrooms, and other attributes. The dataset provides information about the street address; ZIP code; and identifiers for the MSA, country, and state. The dataset is dynamic, as it tracks changes in the listing over time, in particular whether the property is pulled off the market, is relisted, or has its price adjusted.

The analysis is restricted to ZIP code level, but we also conduct robustness tests at the county level. For the analysis, the observations with a missing ZIP code or Federal Information Processing System code are dropped. The analysis is restricted to single-family homes and condominiums. The unit of measure for TOM is daily (sometimes referred to as days on the market), and the observations with negatives entries, exceeding 1,460 days, or missing information are eliminated. Properties with inconsistent information, such as a closed status but categorized as active, accepting backup offers, contingent, deleted, on hold, off market, pending sale, or pending, are eliminated.

The reported variable of TOM gets reset if the property is relisted with a different realtor. For example, a property could be listed with realtor A for six months without selling, pulled off the market for two months, and then relisted with realtor B and sold within two months. The data would report a failed listing of six months and a successful listing of two months. In the absence of major improvements to the dwelling, our view is that the property has taken at least eight months to sell. To capture the effective time that properties are listed before selling or being pulled off the market, we reconstruct the variable TOM by following the property from the initial listing to a complete sale or withdrawal from the market, allowing relistings or withdrawal from the market for less than three months. This three-month threshold seems to capture more than 75 percent of such incidences.

\section{IRS Data}

The main macroeconomic variable available at the ZIP code level is adjusted gross income (income) provided by the IRS. The IRS gathers tax receipts and creates tables by ZIP codes for individual states, including various tax and income-related statistics. In particular, the IRS reports income. A ZIP code is included by the IRS only if the area has more than 10 tax receipts. A tax receipt is an individual's gross income minus tax adjustments. The analysis uses data for the years 2004-15. In the file, there are different income classes given by the IRS. 
The mean income across classes is added up and divided by the total number of returns, giving the average income for a ZIP code for a given year. The data are made real using the personal consumption expenditures index and multiplying by 100 .

\section{FRBNY CCP/Equifax Data}

This dataset contains individual-level data on households' credit reports, and it is available in the RADAR Data Warehouse. The data are a representative 5 percent sample of individuals in the United States with a credit report and Social Security number and are reported on a quarterly basis. For the purposes of this project, the universe of data was aggregated annually at the ZIP code level on a few variables from this vast dataset. In particular, data gathered included several measures of mortgage payment status: the number of current mortgages in a ZIP code and several variables that disaggregated past-due mortgages into buckets by timing. The summary tables and the analysis uses the flags provided by Equifax to remove duplicated individuals during aggregation. The variable defined as the mortgage delinquency rate aggregates the number of mortgages 90 days past due (delinquent), between 90-120 days past due (seriously delinquent), and "severely derogatory." Severely derogatory mortgages have no clear definition from Equifax, but Equifax and other sources suggest that these are mortgages that are at least 120 days past due and also include mortgages in the process of foreclosure, collection, or repossession. The variable for total mortgages is calculated using the measures described above along with current mortgages and mortgages less than 90 days past due. The summary statistics and the regressions report the rate that is calculated as the ratio of mortgages $90+$ days past due (plus those severely derogatory) over the stock of mortgages in a given year.

\section{ZIP-Code-Level Data}

The ZIP-code-level data are from the U.S. Census Bureau's 2010 Decennial Survey of the United States. If a given ZIP Code has population missing from this survey, it is replaced by data from the 2000 Census if possible. These data are used to weight the summary statistics and scatter plots in Figures 6 and 7.

\section{INFORMATION ON WEIGHTING}

\section{ZIP Code Regressions}

The ZIP code regressions are weighted using the number of tax returns in each ZIP code in 2006 as a proxy for population. This proxy is also used in the regressions with the mortgage delinquency rate and mean income as dependent variables.

\section{Summary Statistics}

The summary statistics use weights as well. For the ZIP code summary statistics, 2000 and 2010 Census population data are used as the weights. Because population is fixed per ZIP code and does not vary per year, the static populations of the ZIP codes are used to weight these statistics. 


\section{Famiglietti, Garriga, Hedlund}

\section{ENDNOTES}

1 An extensive summary of the state of this literature is provided by Davis and Van Nieuwerburgh (2015) and Piazzesi and Schneider (2016).

$\underline{2}$ There is a growing literature that measures the extent to which the housing boom was driven by expectations/ beliefs or credit conditions. Plenty evidence indicates that homeowners tend to have overoptimistic expectations about future appreciation. Case and Shiller (2003) found that up to 95 percent of homebuyers in the year 2003 thought that housing prices would appreciate by an astonishing annual average of 9 percent over the next decade. Davis and Quintin (2014) show that during boom-bust periods household expectations adjust sluggishly and households fail to anticipate changes in the value of their home relative to the market value. These notions have been incorporated in models to rationalize boom episodes (i.e., Glaeser, Gottlieb, and Gyourko, 2013; Glaeser and Nathanson, 2015; Adam, Kuang, and Marcet, 2012; Kahn, 2009; and Gelain, Lansing, and Natvik, 2018). Another strand in the macro-housing literature explores the impact of changes in housing finance (i.e., reductions in mortgage rates, relaxation of loan-to-value constraints, and innovations in mortgage lending) on house prices (i.e., Ortalo-Magné and Rady, 2006; Kiyotaki, Michealides, and Nikolov, 2011; Landvoigt, Piazzesi, and Schneider, 2015; and Favilukis, Ludvigson, and Van Nieuwerburgh, 2017).

3 Formalizing the role of frictions in housing transaction is becoming more standard. There is an extensive literature that uses random-matching search techniques from the labor literature (i.e., Wheaton, 1990; Krainer, 2001; NovyMarx, 2009; Ngai and Tenreyro, 2014; and Caplin and Leahy, 2011). More recently the selling behavior evidence provided by Merlo, Ortalo-Magne, and Rust (2015) has provided empirical support for using a directed search model in this article. It is common in this literature to abstract from credit constraints and the financial heterogeneity of buyers and sellers (i.e., Díaz and Jerez, 2013; Albrecht, Gautier, and Vroman, 2016; and Head, Lloyd-Ellis, and Sun, 2014), and this limits the ability to explore the connection among housing illiquidity, foreclosures, and endogenous credit supply. The majority of these papers explore the housing market in isolation, ignoring the impact of house price movements for the broad economy.

4 The appendix contains detailed information on the construction of these variables and different measures of robustness on the variation during the sample period 2005-12.

5 Months' supply is the ratio of houses for sale to houses sold. This statistic provides an indication of the size of the for-sale inventory in relation to the number of houses currently for sale. Months' supply indicates how long the current for-sale inventory would last given the current sales rate if no additional new houses were built.

6 All results presented in this article have been calculated using both TOM and months' supply and are very similar. For ease of presentation, we present the results using TOM because TOM is easy to understand.

\section{REFERENCES}

Adam, Klaus; Kuang, Pei and Marcet, Albert. "House Price Booms and the Current Account," in Daron Acemoglu and Michael Woodford, eds., NBER Macroeconomics Annual 2011. Volume 26. University of Chicago Press, 2012, pp. 77-122; https://doi.org/10.1086/663990.

Albrecht, James; Gautier, Pieter A. and Vroman, Susan. "Directed Search in the Housing Market." Review of Economic Dynamics, 2016, 19, pp. 218-31; https://doi.org/10.1016/j.red.2015.05.002.

Anenberg, Elliot and Kung, Edward. "Estimates of the Size and Source of Price Declines Due to Nearby Foreclosures." American Economic Review, 2014, 104(8), pp. 2527-51; https://doi.org/10.1257/aer.104.8.2527.

Armesto, Michelle and Garriga, Carlos. "Examining the Housing Crisis by Home Price Tier." Federal Reserve Bank of St. Louis Economic Synopses, 2009, No. 34; https://doi.org/10.20955/es.2009.34.

Arslan, Yavuz; Guler, Bulent and Taskin, Temel. "Joint Dynamics of House Prices and Foreclosures." Journal of Money, Credit, and Banking, 2015, 47(1), pp. 133-69; https://doi.org/10.1111/jmcb.12196.

Berger, David; Guerrieri, Veronica; Lorenzoni, Guido and Vavra, Joseph. "House Prices and Consumer Spending." Review of Economic Studies, 2017, 85(3), pp. 1502-42; https://doi.org/10.1093/restud/rdx060.

Boldrin, Michele; Garriga, Carlos; Peralta-Alva, Adrian and Sanchez, Juan. "Reconstructing the Great Recession." Working paper, 2013; https://doi.org/10.20955/wp.2013.006. 
Campbell, John Y. and Cocco, João F. "A Model of Mortgage Default." Journal of Finance, 2015, 70(4), pp. 1495-554; https://doi.org/10.1111/jofi.12252.

Campbell, Sean D.; Davis, Morris A.; Gallin, Joshua and Martin, Robert F. "What Moves Housing Markets: A Variance Decomposition of the Rent-Price Ratio." Journal of Urban Economics, 2009, 66(2), pp. 90-102; https://doi.org/10.1016/j.jue.2009.06.002.

Caplin, Andrew and Leahy, John. "Trading Frictions and House Price Dynamics." Journal of Money, Credit, and Banking, 2011, 43, pp. 283-303; https://doi.org/10.1111/j.1538-4616.2011.00436.x.

Case, Karl E. and Shiller, Robert J. "Is There a Bubble in the Housing Market?" Brookings Papers on Economic Activity, 2003, 34(2), pp. 299-362; https://doi.org/10.1353/eca.2004.0004.

Chambers, Matthew; Garriga, Carlos and Schlagenhauf, Don. "The Postwar Conquest of the Home Ownership Dream." Working Paper 2016-007, Federal Reserve Bank of St. Louis, 2016; https://doi.org/10.20955/wp.2016.007.

Chatterjee, Satyajit and Eyigungor, Burcu. "A Quantitative Analysis of the U.S. Housing and Mortgage Markets and the Foreclosure Crisis." Review of Economic Dynamics, April 2015, 18(2), pp. 165-84; https://doi.org/10.1016/j.red.2015.02.004.

Corbae, Dean and Quintin, Erwan. "Leverage and the Foreclosure Crisis." Journal of Political Economy, February 2015, 123, pp. 1-65; https://doi.org/10.1086/677349.

Davis, Morris A. and Heathcote, Jonathan. "Housing and the Business Cycle." International Economic Review, 2005, 46(3), pp. 751-84; https://doi.org/10.1111/j.1468-2354.2005.00345.x.

Davis, Morris A. and Quintin, Erwan. "On the Nature of Self-Assessed House Prices." Real Estate Economics, 2017, 45(3), pp. 628-49; https://doi.org/10.1111/1540-6229.12168.

Davis, Morris and Van Nieuwerburgh, Stijn. "Housing, Finance and the Macroeconomy," in Gilles Duranton, J. Vernon Henderson and William C. Strange, eds., Handbook of Regional and Urban Economics. Volume 5. Elsevier, 2015, pp. 753-811; https://doi.org/10.1016/B978-0-444-59531-7.00012-0.

Díaz, Antonia and Jerez, Belén. "House Prices, Sales, and Time on the Market: A Search-Theoretic Framework." International Economic Review, 2013, 54(3), pp. 837-72; https://doi.org/10.1111/iere.12019.

Favilukis, Jack; Ludvigson, Sydney C. and Van Nieuwerburgh, Stijn. "The Macroeconomic Effects of Housing Wealth, Housing Finance, and Limited Risk-Sharing in General Equilibrium." Journal of Political Economy, 2017, 125(1), pp. 140-223; https://doi.org/10.1086/689606.

Fisher, Lynn M. and Yavas, Abdullah. "The Value of Equitable Redemption in Commercial Mortgage Contracting." Journal of Real Estate Finance and Economics, 2007, 35(4), pp. 411-25; https://doi.org/10.1007/s11146-007-9064-4.

Garriga, Carlos and Hedlund, Aaron "Housing Finance, Boom-Bust Episodes, and Macroeconomic Fragility." Working Paper, March 2018.

Garriga, Carlos and Hedlund, Aaron. "Mortgage Debt, Consumption, and Illiquid Housing Markets in the Great Recession." American Economic Review, forthcoming.

Garriga, Carlos; Kydland, Finn and Sustek, Roman. "Mortgages and Monetary Policy." Review of Financial Studies, 2017, 30(10), pp. 3337-375; https://doi.org/10.1093/rfs/hhx043.

Garriga, Carlos; Manuelli, Rody and Peralta-Alva, Adrian. "A Macroeconomic Model of Price Swings in the Housing Market." American Economic Review, June 2019, 109(6), pp. 2036-72; https://doi.org/10.1257/aer.20140193.

Garriga, Carlos and Schlagenhauf, Don E. "Home Equity, Foreclosures, and Bailouts.” Working paper, January 2009.

Gelain, Paolo; Lansing, Kevin J. and Navik, Gisle J. "Explaining the Boom-Bust Cycle in the U.S. Housing Market: A Reverse-Engineering Approach." Journal of Money, Credit, and Banking, 2018, 50(8), pp. 1751-82; https://doi.org/10.1111/jmcb.12504.

Genesove, David and Mayer, Christopher. "Loss Aversion and Seller Behavior: Evidence from the Housing Market." Quarterly Journal of Economics, 2001, 116(4), pp. 1233-60; https://doi.org/10.1162/003355301753265561.

Geraradi, Kris; Herkenhoff, Kyle; Ohanian, Lee E. and Willen, Paul. “Can't Pay or Won't Pay? Unemployment, Negative Equity, and Strategic Default." Review of Financial Studies, March 2018, 31(3), pp. 1098-131;

https://doi.org/10.1093/rfs/hhx115. 


\section{Famiglietti, Garriga, Hedlund}

Glaeser, Edward L.; Gottlieb, Joshua D. and Gyourko, Joseph. "Can Cheap Credit Explain the Housing Boom?" in Housing and the Financial Crisis. National Bureau of Economic Research. University of Chicago Press, 2013, pp. 301-59; https://doi.org/10.7208/chicago/9780226030616.003.0008.

Glaeser, Edward L.; Gyourko, Joseph and Saks, Raven. "Why Is Manhattan So Expensive? Regulation and the Rise in in Housing Prices." Journal of Law and Economics, 2005, 48(2), pp. 331-69; https://doi.org/10.1086/429979.

Glaeser, Edward L. and Nathanson, Charles G. "Housing Bubbles" in Gilles Duranton, J. Vernon Henderson, and William C. Strange, eds., Handbook of Regional and Urban Economics. Volume 5. Elsevier, 2015; https://doi.org/10.1016/B978-0-444-59531-7.00011-9.

Guler, Bulent. "Innovations in Information Technology and the Mortgage Market." Review of Economic Dynamics, 2015, 18(3), pp. 456-83; https://doi.org/10.1016/j.red.2014.09.007.

Hatchondo, Juan Carlos; Martinez, Leonardo and Sanchez, Juan M. "Mortgage Defaults." Journal of Monetary Economics, 2015, 76, pp. 173-90; https://doi.org/10.1016/j.jmoneco.2015.09.011.

Head, Allen; Lloyd-Ellis, Huw and Sun, Hongfei. "Search, Liquidity, and the Dynamics of House Prices and Construction." American Economic Review, 2014, 104(4), pp. 1172-210; https://doi.org/10.1257/aer.104.4.1172.

Hedlund, Aaron. "The Cyclical Dynamics of Illiquid Housing, Debt, and Foreclosures." Quantitative Economics, 2016, 7(1), pp. 289-328; https://doi.org/10.3982/QE483.

Hedlund, Aaron. "Failure to Launch: Housing, Debt Overhang, and the Inflation Option." American Economic Journal: Macroeconomics, 2018, 11(2), pp. 228-74; https://doi.org/10.1257/mac.20160371.

Herkenhoff, Kyle and Ohanian, Lee. "The Impact of Foreclosure Delay on U.S. Employment." Review of Economic Dynamics, January 2019, 31, pp. 63-83; https://doi.org/10.1016/j.red.2018.11.002.

Himmelberg, Charles; Mayer, Christopher and Sinai, Todd. "Assessing High House Prices: Bubbles, Fundamentals and Misperceptions." Journal of Economic Perspectives, 2005, 19(4), pp. 67-92; https://doi.org/10.1257/089533005775196769.

Huo, Zhen and Rios-Rull, José-Victor. "Financial Frictions, Asset Prices, and the Great Recession." CEPR Discussion Paper, September 2016, Centre for Economic Policy Research; https://doi.org/10.21034/sr.526.

lacoviello, Matteo. "House Prices, Borrowing Constraints, and Monetary Policy in the Business Cycle." American Economic Review, 2005, 95(3), pp. 739-64; https://doi.org/10.1257/0002828054201477.

lacoviello, Matteo and Neri, Stefano. "Housing Market Spillovers: Evidence from an Estimated DSGE Model." American Economic Journal: Macroeconomics, 2010, 2(2), pp. 125-64; https://doi.org/10.1257/mac.2.2.125.

lacoviello, Matteo and Pavan, Marina. "Housing and Debt over the Life Cycle and over the Business Cycle." Journal of Monetary Economics, 2013, 60(2), pp. 221-38; https://doi.org/10.1016/j.jmoneco.2012.10.020.

Jordà, Òscar; Schularick, Moritz and Taylor, Alan. "Leveraged Bubbles." Journal of Monetary Economics, 2015, 76, pp. S1-S20; https://doi.org/10.1016/j.jmoneco.2015.08.005.

Kahn, James A. “What Drives Housing Prices?" Working paper, June 2009; https://doi.org/10.2139/ssrn.1264048.

Kiyotaki, Nobuhiro; Michaelides, Alexander and Nikolov, Kalin. "Winners and Losers in Housing Markets." Journal of Money, Credit, and Banking, March 2011, 43(2-3), pp. 255-96; https://doi.org/10.1111/j.1538-4616.2011.00374.x.

Krainer, John. "A Theory of Liquidity in Residential Real Estate Markets." Journal of Urban Economics, 2001, 49(1), pp. 32-53; https://doi.org/10.1006/juec.2000.2180.

Landvoigt, Tim; Piazzesi, Monika and Schneider, Martin. "The Housing Market(s) of San Diego." American Economic Review, 2015, 105(4), pp. 1371-407; https://doi.org/10.1257/aer.20111662.

Leamer, Edward E. "Housing Is the Business Cycle," in Proceedings of Housing, Housing Finance, and Monetary Policy: A Symposium Sponsored by The Federal Reserve Bank of Kansas City. Federal Reserve Bank of Kansas City, 2007, pp. 149-233; http://www.kansascityfed.org/publicat/sympos/2007/PDF/Leamer_0415.pdf.

Liu, Zheng; Wang, Pengfei and Zha, Tao. "Land-Price Dynamics and Macroeconomic Fluctuations." Econometrica, 2013, 81(3), pp. 1147-84; https://doi.org/10.3982/ECTA8994. 
Merlo, Antonio; Ortalo-Magné, François and Rust, John. "The Home Selling Problem: Theory and Evidence." International Economic Review, 2015, 56(2), pp. 457-84; https://doi.org/10.1111/iere.12111.

Mian, Atif and Sufi, Amir. "The Consequences of Mortgage Credit Expansion: Evidence from the U.S. Mortgage Default Crisis." Quarterly Journal of Economics, 2009, pp. 1449-96; https://doi.org/10.1162/qjec.2009.124.4.1449.

Mian, Atif and Sufi, Amir. "What Explains the 2007-2009 Drop in Employment?" Econometrica, 2014, 82(6), pp. 2197-223; https://doi.org/10.3982/ECTA10451.

Mian, Atif; Sufi, Amir and Trebbi, Francesco. "Foreclosures, House Prices, and the Real Economy." Journal of Finance, 2015, 70(6), pp. 2587-634; https://doi.org/10.1111/jofi.12310.

Ngai, L. Rachel and Tenreyro, Silvana. "Hot and Cold Seasons in the Housing Market." American Economic Review, 2014, 104(12), pp. 3991-4026; https://doi.org/10.1257/aer.104.12.3991.

Novy-Marx, Robert. "Hot and Cold Markets." Real Estate Economics, 2009, 37(1), pp. 1-22; https://doi.org/10.1111/j.1540-6229.2009.00232.x.

Ortalo-Magné, François and Rady, Sven. "Housing Market Dynamics: On the Contribution of Income Shocks and Credit Constraints." Review of Economic Studies, April 2006, 73(2), pp. 459-85; https://doi.org/10.1111/j.1467-937X.2006.383 1.x.

Piazzesi, Monika and Schneider, Martin. "Housing and Macroeconomics," in John B. Taylor and Harald Uhlig, eds. Handbook of Macroeconomics. Volume 2. Elsevier, 2016, pp. 1547-1640; https://doi.org/10.1016/bs.hesmac.2016.06.003.

Poterba, James M. "Tax Subsidies to Owner-Occupied Housing: An Asset-Market Approach." Quarterly Journal of Economics, 1984, 99(4), pp. 729-52; https://doi.org/10.2307/1883123.

Rupert, Peter and Wasmer, Etienne. "Housing and the Labor Market: Time to Move and Aggregate Unemployment." Journal of Monetary Economics, 2014, 79, pp. 24-36; https://doi.org/10.1016/j.jmoneco.2011.10.008.

Saiz, Albert. "Geographic Determinants of Housing Supply." Quarterly Journal of Economics, 2010, 125(3), pp. 1253-96; https://doi.org/10.1162/qjec.2010.125.3.1253.

Shiller, Robert. "Understanding the Recent Trends in House Prices and Home Ownership." NBER working paper No. 13553, October 2007. National Bureau of Economic Research; https://doi.org/10.3386/w13553.

Wheaton, William C. "Vacancy, Search and Prices in a Housing Market Matching Model." Journal of Political Economy, 1990, 98(6), pp. 1270-92; https://doi.org/10.1086/261734. 
